\title{
STUDIES CONCERNING THE ESSENTIAL \\ NATURE OF ALUMINUM AND SILICON \\ FOR PLANT GROWTH
}

BY

ANNA L. SOMMER

Unimarsity of California Publications in Agricultural Sciences

Volume 5, No. 2, pp. 57-81, 2 figures in text

unvarTy of CALTOXNAT

LIDRAR

COLSCE OF ACWCULTUKL

PAVM

UNIVERSITY OF CALIFORNIA PRESS

BERKELEY, CALIFORNIA 


\section{UNIVERSITY OF OALIFORNIA PUBLIOATIONS}

Note.-The University of Calfornia Publications are offered in exchange for the publs cations of learned societios and lastitutions, wiversities and libraries. Complete lists of all the publications of the University will be sent upon request. For sample copies, List: of publications and other information, address the MANAGEB OF THE UNIVERSITY PRESS, BERKELEY, CALIFORNIA, U.S.A. All matter sent in exchange should b addressed to THE EXCHANGE.DEPARTMENT, UNIVERSITX ITBRARY, BEREFTEY, CATIFORNIA, U. S. A.

Publications of the University of California Press may also be obtained from MrE CAMBRTDGE UNIVERSITY PRESS, FETTER LANE, IONDON, E.C. 4, ENGI.AND, to which orders originating in Great Britain and Ireland should be sent.

AGRICULTURAT SCIENCES.-C. B. Iipman, H. S. Reed, R. F. Clausen, Fditors. Price per volume, \$5. Volume 1 (587 pages), 3 (509 pages), and 4 (450 pages) comploted. Volumes 2 and $b$ in progress.

Vol. 2. 1. Studies in Juglans. I. Study of a Now Form of Juglans californica Watson, by Ermest B. Babcock. Pp. 1-46, plates 1-12. December, 1918

2. Studies in Juglans. II. Further Observations on a New Varlety of Juglans californica Watson and on Certain Supposed Walnut-Oak Hybrids, by Emest B. Babcock. Pp. 47-70, plates 13-19. October, 1914

3. Studies in Juglans. III. (1) Further Evidence that the Oak-like Wainut Origlnates by Mutation; (2) A Parallel Mutation in Juglans hindsi (Jepson) Sargent, by Ermest B. Babcock. Pp. 71-80, plates 20-21. September, 1916

4. Mutation in Matthiola, by Howard B. Frost. Pp. 81-190, plates 22-35. November, 1919

5. Interspecific Hrbrids in Crepis. I. Crepis capillaris (I.) Wallr. $\times$ C. Teo torum I., by Emest B. Babcock and Julius L. Collins. Pp. 191-204, plates 36-38. October, 1920

Inheritance in Crepis capillaris (I.) Wallr. I. Inbreeding and Crossbreeding in Crepis capillaris (I.) Wallr., by Julius I. Collins. Pp. 205-216, plates 39-41. November, 1920

7. Inheritance in Crepis capillaris (I.) Wallr. Ir. Inheritance of Some Morphological Characters in Crepis capillaris, by Venkata Rall. Pp. 217-242, plates $42-43,3$ figures in toxt. June, 1923

8. Microsporogenesis of Ginkgo biloba I. with especial reference to the Distribution of the Plastids and to Cell Wall Formation, by Margaret Campbell Mann. Pp. 243-248, plate 52. September, 1924

9. Inheritance in Crepis capillaris. (I.) Wallr. III. Nineteen Morphological and Three Physiological Characters, by J. I. Collins. Pp. 249-296, plates 45-52. December, 1924.

10. Chromosome Number and Individuality in the Genus Crepis. I. A Comparative Study of the Chromosome Number and Dimensions of Nineteen Species, by Margaret Campbell Mann. 'Pp. 297-314, plate 53. March, 1925

11. Chromosome Number and Individuality in the Genus Crepis. II. The Chromosomes and Taxonomic Relationships, by Ernest Brown Babcock and Margaret Mann Lesley. Pp. 315-341, 7 figures in text. March, 1926.

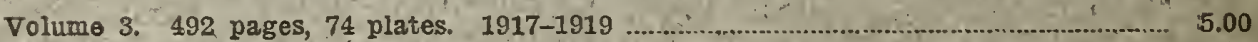

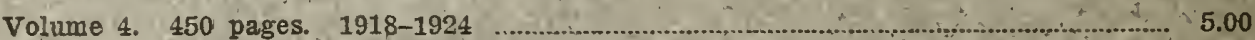

Vo1. 5. 1. Growth and Differentiation in Apricot Trees, by H. S. Reed. Pp. 1-55, 18 figures in text. September, 1924

2. Studies Concerning the Essential Nature of Aluminum and Silicon for Plant Growth, by Anna I. Sommer. Pp. 57-81, 2 figs, in text. May; 1926

AGRICULTURE,-The Publications of the Agricultural Experiment Station are sent gratis to citizens of the State of California For detailed information regarding them address the Agricultural Experiment Station, Berkeley, California. 
STUDIES CONCERNING THE ESSEN'TIAL NATURE OF ALUMINUM AND SILICON FOR

PLANT GROWTH

BY

ANNA L. SOMMER 
University of Califorxia Publications in Agricultural Sciences Volume 5, No. 2, pp. 5i-81, 2 figures iu text Issued May 6, 1926

\section{University of California Press} Berkeley, California

\section{Cambridge Uxiversity Press}

LoNdon, ENGLAND 


\title{
STUDIES CONCERNING THE ESSENTIAL NATURE OF ALUMINUM AND SILICON FOR PLAN'T GROW'TH
}

BY

\author{
ANNA I. SOMMER
}

\section{INTRODUCTION*}

One of the first problems to occupy the attention of the plant physiologist was the determination of the essential nature of elements supplied by the soil. The question appeared to be answered about the middle of the last century by Knop, who demonstrated that plants grew well in a dilute solntion of $\mathrm{KNO}_{3}, \mathrm{MgSO}_{4}, \mathrm{KH}_{2} \mathrm{PO}_{4}$, and $\mathrm{CaSO}_{4}$, to which a trace of $\mathrm{FePO}_{4}$ had been added. Until recently, however, investigators have failed to consider the fact that possible essential elements might be introduced as impurities. Since some elements are required only in very small amounts, experiments to ascertain whether or not they are essential can be conducted successfully only when purified salts are employed. It is therefore not surprising that negative results have followed the few investigations of other elements than those named by Knop.

Among these investigations are those of Mazé, ${ }^{8}$ McHargue, ${ }^{9}$ and Warington. ${ }^{17}$ Mazé was the first to use purified salts and reported marked improvement in growth when he added aluminum, boron, fluorin, and iodine to solution cultures in which maize was grown. McHargue proved manganese to be essential to all plants with which he worked; these including beans, wheat, spinach, and radishes. Warington found that, although boron may not be essential for all plants, it is essential for certain of the legumes.

All plants in their natural environment absorb aluminum and silicon, and the studies reported in this paper were conducted to get additional evidence concerning the essential nature of these elements, as very little has been done under sufficiently controlled conditions or including a large enough number of plants to prove that these elements were actually essential.

\footnotetext{
* The writer wishes to acknowledge her indebtedness to Professor C. B. Lipman for helpful counsel during the course of these investigations; the investigation concerning silicon was suggested by him.
} 
Sinee silieon and aluminum are present in the soil in sueh large amounts and are absorbed by the plant, further studies as to whether or not these elements are essential are important.

There is suffieient evidenee to slow that aluminum is toxie at low eoneentrations to higher plants. Miyake ${ }^{11}$ and Mirasol ${ }^{10}$ have shown that the aluminum ion is more toxie than the hydrogen ion of the same eoncentration. Rupreeht, ${ }^{13}$ on investigating infertility of soils after eontinued use of $\left(\mathrm{NH}_{4}\right)_{2} \mathrm{SO}_{4}$, found an inerease in soluble aluminum. In experiments with peas in eulture solutions he found 21.6 p.p.m. (the lowest eoneentration used) to be toxie. Kratzman ${ }^{5}$ reported aluminum salt toxie to a number of higher plants at a eoneentration of .005 per eent, and slightly stimulating at .0001 per eent. In a preliminary experiment reported in the same paper, this investigator found 8 p.p.m. to be very toxie to wheat, and some depression in growth at 2 p.p.m. Abbot, Conuor and Smalley ${ }^{1}$ found the toxieity of eertain soils to be eaused by soluble aluminum salts, while Hartwell and Pember $^{3}$ were able to explain why eertain aeid soils were more toxie to barley than to rye by showing that barley is partieularly sensitive to aluminum.

Aluminum was one of the elements whieh Mazés found neeessary for the normal development of maize. The salts he used were highly purified and his results indieate that fluorine, iodine, and espeeially boron are also neeessary. Mazé, however, used only a small number of plants in eaeh of three experiments and marked irregularities oceur in some of his data. Further investigations of a similar nature are therefore neeessray before definite eonelusions ean be drawn coneerning the essential nature of these elements for maize. This eriticism does not hold for boron, for in all eases marked depression was evident if boron was lacking.

Although Stoklasa ${ }^{13}$ used so far as we know only the so-ealled ehemieally pure salts, he obtained striking improvements in growth when he added aluminum to solution and siliea jelly cultures in whieh he grew eertain hydrophytes. Juncus effusus in solution eulture without aluminum died in from 56 to 69 days, and Glyceria aquatica in silica jelly eultures died in 22 days. Other hydrophytes, although they did not die in the solution without aluminum, showed remarkable improvement in growth whel it was added. He also found that aluminum stimulated the growth of mesophytes sueh as Hordeum distichum, Triticum vulgare, and avena sativa, but that xerophytes, including Allosurus crispus, Polygonatum officinale, and Iris bohcmica 
were not affected by the addition of 13.5 p.p.in. or 20 p.p.m. aluminum to the solution enltures in which they were grown but were injured by 27 p.p.m. However, since he added 0.5 grams $\mathrm{Ca}_{3}\left(\mathrm{PO}_{4}\right)_{2}$ to the solutions and aerated daily, the amounts in solntion are probably not represented by the amounts added. Judging from the results of other investigators (Ruprecht ${ }^{13}$ ), Abbot, Comnor and Smalley, ${ }^{1}$ Hartwell and Pember, ${ }^{3}$ and the writer, even the smallest amount added would have been toxic to mesophytes and xerophytes if not to hydrophytes had it remained in solution. Stoklasa attributes the difference in the requirements for ahuminum of these three groups of plants to the difference in the amounts to which they have become accustomed, owing to their environments.

The earliest ideas regarding the rôle of silicon in plant growth were based upon speculation. Sir Humphrey Davy2 in his book, "The Elements of Agricultural Chemistry", (1814), stated, "The siliceous epidermis of plants serves as a support, protects the bark from the action of insects and seems to perform a part in the economy of these feeble vegetable tribes (Grasses and Equisetales) similar to that performed in the animal kingdom by the shell of crustaceous insects." Liebig attributed the rigidity of the stalks of cereals to potassium silicate and explained the lodging of wheat by assuming a defieieney of silicon. Pierre, ${ }^{12}$ on the other hand, claimed to have evidence that, other things being equal, wheat with the highest silicon content was most likely to lodge, and agreed with Sachs ${ }^{13}$ that it was lignification of tissues, favored by air, light, and the absence of too much water, which prevented lodging. The opinions of later investigators are just as contradictory.

Jodin ${ }^{4}$ was one of the first to make a special attempt to determine whether or not silicon is essential to plant growth. Like other investigators, he grew his plants in glass containers and made no attempt to purify the salts used for the solutions. He grew four generations of plants. The plants grew well, but the fourth generation produced no seed. This he thought was accidental and concluded that silicon is probably not essential. No conclusion, however, can be drawn, since his plants were not really grown in the absence of silicon and he had no control plants to show any beneficial effects which might have been obtained with a larger amount of silicon. An analysis of his second generation plants showed 0.2 per cent of the dry weight to be $\mathrm{SiO}_{3}$ (reported as such by the author). 
Working a little later (1883) with only one generation of plants, Krenzhage and Wolff $^{6}$ earried on expeirments with oats in solution cultures, and usually, though not always, obtained an increase in dry weight when $\mathrm{H}_{2} \mathrm{SiO}_{3}$ was added. The increase in grain was, however, marked and consistent. They used uncoated glass containers.

Sprecher ${ }^{15}$ also worked with oats in solution cultures. He used three types of solutions and varied the conditions as follows: solutions without $\mathrm{H}_{2} \mathrm{SiO}_{3}$ in jars coated with paraffin, solutions without $\mathrm{H}_{2} \mathrm{SiO}_{3}$ in uncoated glass containers, and solutions with $\mathrm{H}_{2} \mathrm{SiO}_{3}$ in uncoated glass containers. He obtained marked increases witl $\mathrm{H}_{2} \mathrm{SiO}_{3}$ and although he does not say that silicon is essential he considers it very important in plant metabolism. The plants in paraffined jars had very stunted root systems, but the total dry weight was abont the same as that for plants without $\mathrm{H}_{2} \mathrm{SiO}_{3}$ in uncoated jars. He suggests that the glass may have a stimulating effect on root development but makes no mention of the toxic effect of paraffin. The analyses of his plants showed more silicou than could be accounted for by that fonnd in the seed so that in his work, as in the work of earlier investigators, silicon was not entirely eliminated.

\section{TECHNIQUE OF THE PRESENT EXPERIMENTS}

All plants employed in these experiments were grown in solution cultures in glass jars. In most of the experiments one-quart or twoquart mason jars were employed, paraffined corks being utilized as supports for the plants. In two cases large glass containers of 16 liter capacity were used, these being made by cutting the tops off of 5-gallon carboys. Wooden covers were made for the large containerstwenty-four holes being bored in eacle and the board thoroughly impregnated with hot paraffin.

In order to prevent traces of the elements in question from being dissolved ont of the glass, the containers were coated for the first series with paraffin, and for the succeeding series with Valspar, a resistant rarnish. A coat of Valspar was applied and allowed to dry over night, the container then being baked for half an hour at $110^{\circ}$ to $140^{\circ} \mathrm{C}$. Two coats of Valspar were applied in this namer.

In order to dissolve out, as far as possible, the solnble matter from the Valspar, the containers were filled with distilled water. to which 20 c.e. concentrated $\mathrm{HCl}$ had been added, and were allowed to stand 
for two days. This dilute solution of acid was then removed, the jars rinsed, filled with distilled water, and kept filled for a period of ten days. The water was changed every other day.

Redistilled water was used in making up the solutions and its only contact with glass was while it was being collected in pyrex glass containers. The salts used in making up the solutions were tested for the elements to be eliminated.

The alizarin test was used for aluminum and was found very sensitive (one part in ten million) in the absence of interfering ions. When traces of aluminum were found, the salts were either purified or made up from the elements or from compounds containing no aluminum. Attempts to purify $\mathrm{KI}_{2} \mathrm{PO}_{4}$ by recrystalization were unsuceessful, but $\mathrm{H}_{3} \mathrm{PO}_{4}$ and $\mathrm{K}_{2} \mathrm{CO}_{3}$, aluminum free, were obtained and the salt prepared from them. For the first series magnesium was supplied in the form of $\mathrm{Mg}\left(\mathrm{NO}_{3}\right)_{2}$ made from the metal and redistilled $\mathrm{HNO}_{3}$. $\mathrm{CaSO}_{4}$ was purified by washing, first with $\mathrm{H}_{2} \mathrm{SO}_{4}$ and then with redistilled water. $\mathrm{KNO}_{3}$ was obtained which gave no test for aluminum. Since the nitrate ion interferes with the alizarin test, it was first decomposed.

In the silicon series $\mathrm{CaSO}_{4}, \mathrm{KNO}_{3}$, and $\mathrm{MgHPO}_{4}$ were used. The $\mathrm{CaSO}_{4}$ was prepared from $\mathrm{CaCl}_{2}$ and $\mathrm{H}_{2} \mathrm{SO}_{4}$, and, since separating $\mathrm{SiO}_{2}$ entirely from $\mathrm{CaSO}_{4}$ as such would be very difficult, $\mathrm{HCl}$ was added to a solution of $\mathrm{CaCl}_{2}$ to precipitate the silicon as $\mathrm{H}_{2} \mathrm{SiO}_{3}$. The solution was then evaporated to dryness and heated for half an hour at $120^{\circ} \mathrm{C}$. The residue was dissolved and filtered. This process was repeated several times and the $\mathrm{CaSO}_{4}$ was then precipitated from the $\mathrm{CaCl}_{2}$ solution with $\mathrm{H}_{2} \mathrm{SO}_{4}$. The $\mathrm{CaSO}_{4}$ was washed free from acid with redistilled water. $\mathrm{KNO}_{3}$ was purified by evaporating the solution to dryness in the presence of $\mathrm{HNO}_{3}$, heating at $120^{\circ} \mathrm{C}$. for half an hour, redissolving, and filtering. This process was repeated several times and the salt was then reerystallized. The $\mathrm{MgHPO}_{4}$ was found to contain only 0.2 milligram $\mathrm{SiO}_{2}$ per 10 grams of the salt. The only attempt to purify it was by trying to dissolve out the silicon compounds. This was done by agitating 100 grams of $\mathrm{MgHPO}_{4}$ for eight hours in a 20-liter, Valspar-coated bottle. The first solution was discarded, the second was used in making up the culture solutions to which silicon was added, and the final was used for the silicon-frec solutions. It was hoped in this way to eliminate most of the silicon; other methods of purifying this salt seemed less satisfactory. 
With the exception of Mazé (working with aluminum), no investigator in testing the essential nature of aluminum or silicon made any effort to exclude dust. Since these elements are omnipresent and are the principal constituents of dust, it would seem necessary to exclude the latter in such experiments. To minimize contamination from this source, all plants, excepting those of the first series (wheat, grown ont of doors), were grown in glass chambers in the greenhouse. These chambers were four feet high, three feet wide, and long enough to accomnodate the number of jars in a series. The glass extended upward from a point just below the tops of the containers, a small space near the top being left unenclosed for ventilation.

The positions of the individual containers were frequently interchanged within the chamber in order to equalize the amount of light receivel.

\section{EXPERIAENTAL ALEMINLU SERIES}

Wheat was used in the first experiment in which the effect of aluninum on plant growth was studied. The seeds were germinated in the usual way on paraffined mosquito netting. When the seedlings were a week old, the remains of the old seeds were removed and the plants transferred to the solutions to be tested.

The salts used for the eulture solutions in this experiment were chosen because they were the first group containing the necessary elements which the writer obtained free from aluminum. The composition of the solution was as follows:

\begin{tabular}{|c|c|}
\hline \multirow{2}{*}{$\mathrm{KNO}_{2} \quad-20$} & Gm. per 1 \\
\hline & .358 \\
\hline $\begin{array}{lll}\mathrm{CaSO}_{4} & \\
\mathrm{MIg}\left(\mathrm{NO}_{3}\right)_{2} 6 \mathrm{H}_{2} \mathrm{O} & \end{array}$ & .500 \\
\hline $\begin{array}{l}\mathrm{Ig}\left(\mathrm{NO}_{3}\right)_{2} 6 \mathrm{H}_{2} \mathrm{O} \\
\mathrm{KH}_{2} \mathrm{PO}_{4}\end{array}$ & \\
\hline $\mathrm{SO}_{4}$ & Trace \\
\hline
\end{tabular}

'l'here were six groups of plants in each series. The plants were grown in the following solutions:

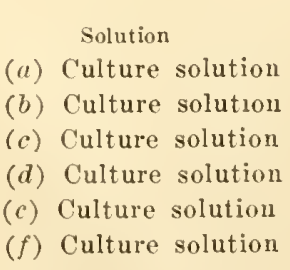

* Aluminum added
p.p.n.
0
2
4
6
8
0

Remarks

Purified salts

Purified salts

Purified salts

Purified salts

Purified salts

Unpurified salts

* Aluminum was added in the form of aluminum sulphate. 
The unpurified salts used were the so-called "chemically pure" salts. Each group consisted of five cultures of four plants each. The containers were one-quart mason jars. The plants were grown out of doors in a place fairly well protected from wind.

\section{OBSERVATIONS}

April 8. Plants in umpurified salts were tillering well. Those in solutions of purified salts with and without aluminum were much smaller. These, especially the ones with 8 p.p.m. aluminum showed depression in root growth and top development.

April 15. Plants in solutions of unpurified salts were mueh the best. Plants in solutions of purified salts with the addition of 2 p.p.m. aluminum lad better tops and longer roots than those without aluminum. All plants in solutions containing more than 2 p.p.m. of aluminum were smaller than those in solutions containing none.

April 23. A rather strong wind carrying a great deal of dust oceurred.

April 30. Solutions changed. All plants in solutions of purified salts with no aluminum, and some of those in solutions witl 2 p.p.m. aluminum, were beginning to tiller. Tops and roots of all plants were making letter growth. There was less difference between the size of the tops of the plants containing 8 p.p.m. aluminum and those of the other groups than there had been.

Roots of plants in solutions containing 2 and 4 p.p.m. aluminum were longer and more branched than those in solutions of purified salts without aluminum.

May 5. Plants in solutions without aluminum were making rapid growth.

May 22. Plants harvested.

Plants in solutions with no aluminum were well tillered and nearly as good as those in solutions of unpurified salts.

2 p.p.m. alumiuum. Some plants had as many as three tillers; some had only a single stalk.

4 p.p.m. Plants were very variable; some were very small while others liad a few tillers and good root systems.

6 p.p.m. Stalks were thick, had few tillers and root systems were greatly depressed.

8 p.p.m. All plants had rery small tops and short roots.

There was a marked difference in the growtl of the plants in the group witl purified salts without aluminum after the wind storm. Since this was probably due to contamination by dust, none of the plants were weighed.

Although this series was not conclusive as to whether or not aluminum is essential to plant growth, it showed the toxicity of aluminum and indicated that 2 p.p.m. is too large an amount to be added to cultures of wheat where a stimulating effect is desired. 


\section{Aluminum Series with Peis}

The type of solution used was the same as that in the preeeding experiment exeept that 2 p.p.m. nuanganese in the form of $\mathrm{MnSO}_{4}$ was added.

Since 2 p.p.m. aluminum had been found to depress the growth of wheat, 1 p.p.m. was the highest eoneentration used in this series. The solutions employed were as follows:

Solntion
(a) Culture solution
(b) Culture solution
(c) Culture solution
(d) Culture solution

Aluminum added
p.p.m.
0
$\frac{1}{2}$
1
0

\author{
Remarks \\ Purified salts \\ Purified salts \\ Purified salts \\ Unpurified salts
}

There were eight cultures with four plants per eulture to each group. The containers were one-quart mason jars. The seed was germinated on paraffined mosquito netting and the cotyledons removed before the plants were transferred to the eulture solutions on August 23.

\section{OBSERVATIONS}

September 6. The plants in solutions of purified salts without aluminum were beginning to bloom and appeared smaller than the others.

September 10. Plants in series with aluminum and with unpurified salts were beginuing to bloom.

September 28. Solutions changed.

October 18. Plants harrested.

All plants except fom, in the solutions of purified salts without almminum, had reached maturity and stopped growing. These four had gone through the cycle of growth and then sent out new growth and produced another lot of flowers. These plants weighed more than the others in this group.

The average weight per plant and the average weight of seed per plant are given in table 1 .

Although there was 110 gain in the total dry weight with 1/2 p.p.m. ahmminum, there seems to be a slight gain in the weight of the seed. With 1 p.p.m. aluminum there was a notieeable gain in both seed and dry weight. The plants grown in solutions of unpurified salts were the best.

Nearly all work eoneerning the essential nature of elements has been done with seed from plants which have been grown in the presence of the element in question, the work of Jodin already cited being an exception. It seems not unlikely that, when an element is needed in a 
very small quantity, the seed may contain enough to allow fair if not normal growth of the plant when this element is lacking in the solution. The second generation, however, should show the need of this element to a much greater extent, and it was therefore decided to use seed grown with and without aluminum for second-generation work.

Seed of the plants grown in solutions (1) of purified salts with no aluminum, and (2) with 1 p.p.m. aluminum, and (3) of unpurified salts were germinated. The seed in all cases germinated well, but the seedlings from seed of plants grown in purified salts without aluminum were smaller than those of the two other groups.

\section{TABLE 1}

Dry Weight of Pea Plants and Sefd Grown in Solutions of Purified Salts With and Without Aluminem axd in Solutions of Unpurified Salts

\begin{tabular}{|c|c|c|c|}
\hline Treatment & $\begin{array}{l}\text { Number of } \\
\text { plants }\end{array}$ & $\begin{array}{l}\text { dry weight } \\
\text { per plant } \\
\text { in grams }\end{array}$ & $\begin{array}{l}\text { of seed per } \\
\text { plant in } \\
\text { grams }\end{array}$ \\
\hline No aluminum ........ & .. 32 & $.49 \pm .02$ & $.22 \pm .01$ \\
\hline Aluminum $\frac{1}{2}$ p.p.m. & 32 & $.48 \pm .01$ & $.25 \pm .01$ \\
\hline Aluminum 1 p.p.m. & 32 & $.55 \pm .02$ & $.28 \pm .01$ \\
\hline Unpurified salts .... & 32 & $.59 \pm .02$ & $.31 \pm .01$ \\
\hline
\end{tabular}

After the plants were transferred to the eulture jars in the greenhouse, the roots of the plants of both groups in the solutions of purified salts became infected by fungi and died. Those in solutions of unpurified salts were not noticeably attacked.

\section{Altminum Series with Millet}

Since work with silicon was being earried out at the same time, groups of plants with silicon and aluminum and with silicon alone were included in this series. The salts, however, were purified in respect to aluminum only.

Golden millet was the variety used in this experiment.

A lot of especially purified salts including $\mathrm{MgSO}_{4}$ aluminum free (as shown by analyses) was obtained from J. G. Baker \& Co., and magnesium was therefore supplied in the form of $\mathrm{MgSO}_{4}$.

The composition of the solution was as follows:

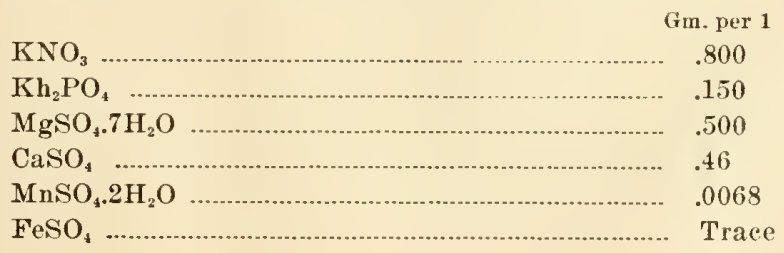


Two-quart mason jars were used. Twenty-four cultures of four plants each were set up in the following solutions:

\begin{tabular}{lll} 
Solution & \multicolumn{1}{c}{ Treatment } & \multicolumn{1}{c}{ Remarks } \\
(a) Culture solution & Nothing added & Purified salts \\
(b) Culture solution & Aluminum 1 p.p.m. & Purified salts \\
(c) Culture solution & Aluminum 1 p.p.m. and $\mathrm{H}_{2} \mathrm{SiO}_{3}$ & Purified salts \\
(d) Culture solution & $\mathrm{H}_{2} \mathrm{SiO}_{3}$ & Purified salts
\end{tabular}

The $\mathrm{H}_{2} \mathrm{SiO}_{3}$ was prepared by precipitation from $\mathrm{Na}_{2} \mathrm{SiO}_{3}$ with $\mathrm{H}_{2} \mathrm{SO}_{4}$. The gel was washed until the rashings gave no test for sulphate ion.

The seed was germinated on cheesecloth and the seedlings transferred to the culture solutions on August 6 .

\section{OBSERVATIONS}

September 10. All plants were making good growth. Those without Al or Si appeared smaller than those of the other groups.

September 17. First heads (2) appeared of the group with Al.

September 21. First heads (2) of group with both Al and Si. Al group 8 heads. September 29. Al group 15 heads, Al and Si group 6 heads, Si group 2 heads. Most of the plants in the group with both $\mathrm{Al}$ and $\mathrm{Si}$ were turning yellow. The roots were infected by fungi.

Oetober 3. First head appeared in the group without Si or Al. Al group 24 beads, Al and Si 17 heads, Si 11 heads. Most plants of the Al and Si group were quite yellow. The plants of the group without Al or Si were producing new leaves at the base which grew rery little, giving the plants a tufted appearance.

October 15. Leaves of a number of plants of the groups with Al and Si were quite yellow. The roots appeared to be infected by fungi.

October 20. A number of plants of the group without Al or Si appeared to be dying. Their roots were in poor condition. More plants of the other groups were infected by fungi, and a number of plants had dies.

November 6. Cultures were harvested where all plants were dead or nearly dead.

Number of plants harvested.
Al and si group 68
Si group 24
No Al or Si group 20
Al group
20

November 30 . Remaining eultures were harvested.

Total number of plants dead from fungi:
Al and Si group
74
Si group
46
No Al or Si group 37
Al group
42

The roots in most eases were matted together, and were therefore weighed per culture (groups of four) and averaged. The average weights of roots and tops, the arerage length of the tops, and the total weight of heads and of seed are given in table 2. 
Since the plants of the group without aluminum and silicon were least affected by fungi, the differences shown are minimum differences. The plants of the group with both aluminum and silicon were so badly injured that they could not be considered. In the earlier stages of growth, however, they did much better than plants grown without silicon and aluminum.

\section{TABLE 2}

Description of Millet Plants Grown in Solutions of Purified Salts With and Without Aluminum axd Silicon

$\begin{array}{lcccc} & \text { No } \mathrm{Al} \text { or } \mathrm{Si} & \mathrm{Al} & \mathrm{Si} & \mathrm{Al} \text { and } \mathrm{Si}^{*} \\ \text { Average dry weight of roots, gms. } & .11 & .14 & .13 & .10 \\ \text { Average dry weight of tops, grams } & .41 \pm .08 & .57 \pm .11 & .62 \pm .10 & .49 \pm .07 \\ \text { Average length of top in cm. ........... } & 25 \pm 7 & 41 \pm .02 & 34 \pm 9 & 33 \pm 6 \\ \text { Total weight of heads in grams....... } & 2.64 & 11.50 & 4.50 & 3.10 \\ \text { Total weight of seeds in grams ........ } & .23 & 4.98 & .40 & .25\end{array}$

* Plants badly affected by fungi.

Although the aluminum and silicon groups were in cvery way better than the group without silicon and aluminum, the most striking difference was shown by the seed. The weight of secd from the group with silicon was nearly twice, and that from the group with aluminum 21.6 times, as large as that of the group without silicon or aluminum. Morcover, $0.17 \pm$ grams of the seed from the serics without aluminum or silicon came from one culture, while the other 24 cultures produced only 0.054 grams.

\section{Second Generation Aluminum Series}

In this series, seeds of plants grown in the preceding experiment with and without aluminum were used to grow a second generation in order to learn the effect of the absence of aluminum. All the seeds from the group without aluminum or silicon, and an equal number from the group with aluminum, were taken for germination. The seed from the large culture of the group without aluminum or silicon was kept separate from that of the rest of the group. The total number of seeds used from each group was 90 . In the case of those without aluminum there were $6 t$ seeds from the large culture, and 26 from the other 24 cultures. The percentage germination for the former was 90.6 per cent, and for the latter 65.5 per cent. All seed from cultures with aluminum germinated. The seedlings of the aluminum group were vigorous and uniform in size; those of the group without ahuminum were quite variable. The seedlings are shown in figure 1. 
The seeds were germinated on netting eoated with Valspar; the germinating dishes were also covered with Valspar, and purified salts were used for the solutions.

Seventy-two seedlings of each group-all of the group without ahminum which were large enough - were transferred to eulture jars. The solutions and containers were of the same kind as those employed for the first generation.

After being transferred to the final solutions the plants of the group with aluminum did not do so well as those of the group withont it. At the end of two weels some of the plants of the group without aluminum were larger than those of the group with aluminum. The

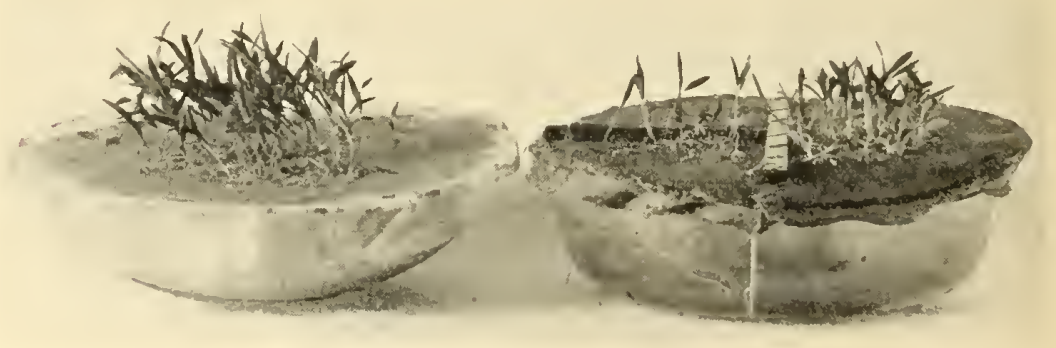

Fig. 1. Millet seedlings.

Left: From seed grown with aluminum.

Right: From seed grown without aluminum.

roots of most of the plants in the aluminum group, and some in the group without aluminum, appeared to be infeeted with fungi about the end of the sixth week. They were probably infeeted earlier but not to an extent that eould be easily notieed. At the end of twelve weeks some of the plants in the group with aluminum were dead. There were, however, five plants with large heads, which appeared to be filling, and seven plants with smaller heads. The plants with the large heads were eorrespondingly large plants, and, although their roots were not in good eondition, they were better than those of the other plants in that group. In the group without aluminum only two small heads developed.

In spite of the fact that the plants of the aluminum group were more severely injured by fungi, they produeed more and better heads than the group without; the leaves also of those plants not too badly injured were broader and more normal in appearanee. 
The series was not weighed because the fungal attack was too severe to allow sufficient growth to make the figures significant.

In experiments similar to the foregoing with peas and millet, the degree of stimulation caused by aluminum was quite different. It may be, inasmuch as the pea has a much larger sced, and therefore probably more stored aluminum, that it may need less additional aluminum for its development. The fact that nearly all pea plants in solutions without aluminum produced viable seeds makes it appear that their

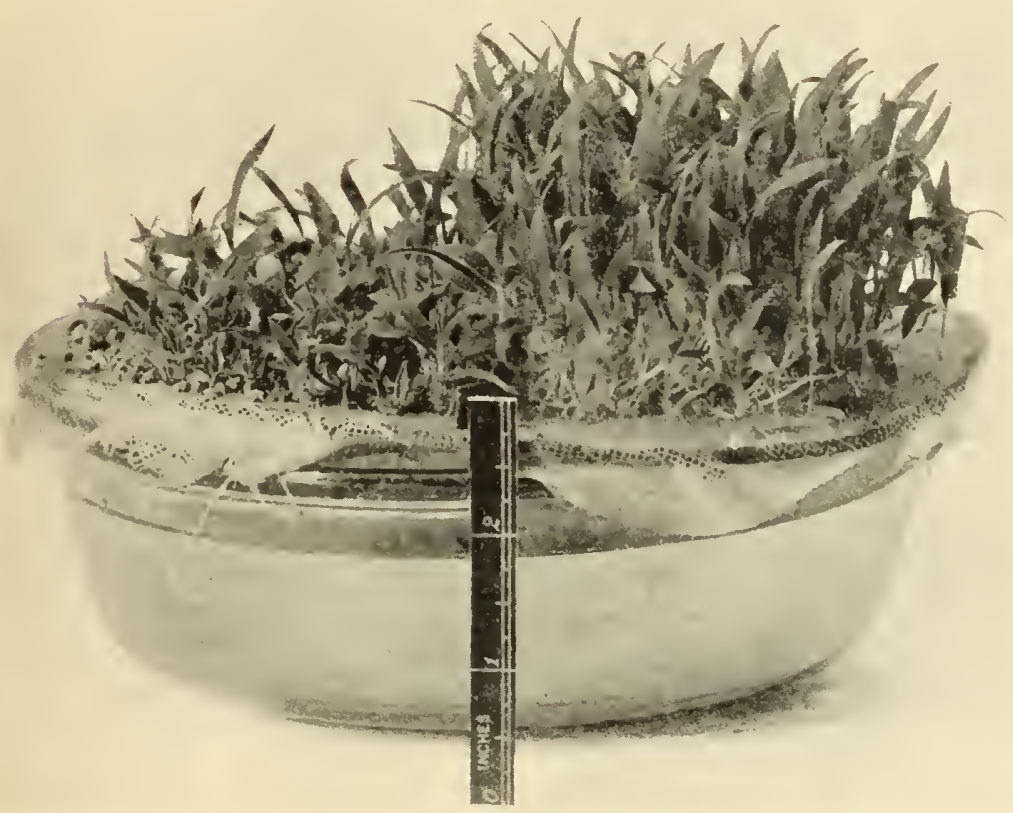

Fig. 2. Millet seedlings.

Left: From seed grown without silicon.

Right: From seed grown with silicon.

need was more nearly supplied than that of the millet, rather than that 1 p.p.m. ahuminum was insufficient. It would therefore be necessary to grow several generations in order to determine whether or not this element is essential to the growth of peas.

The results with millet, however, suggest very strongly that aluminum is essential to its growth. The fact that three-fourths of the seeds of plants grown in solutions without aluminum came from a single culture, while the other twenty-four cultures yielded only a very small amount, makes it appear quite probable that the good growth of this culture was due to contamination with aluminum. 


\section{Experiments with Silicon}

Rice was chosen for the first experiment in which to study the effeet of silicon on plant growth because of the large amount of this element found in its ash.

The eulture solution was made up as follows:

$\begin{array}{ll} & \text { Per liter } \\ \mathrm{KNO}_{3} & .78 \mathrm{gm} . \\ \mathrm{CaSO}_{4} \text { saturated solution } & 400 \text { c.e. } \\ \mathrm{MgHPO}_{4} \text { saturated solution } & 500 \text { e.e. } \\ \mathrm{FeSO}_{4} & \text { Trace }\end{array}$

Silieon was added in the form of $\mathrm{H}_{2} \mathrm{SiO}_{3}$ jelly. This was precipitated from J. G. Baker 'C. P.' $\mathrm{Na}_{2} \mathrm{SiO}_{3}$, with $\mathrm{H}_{2} \mathrm{SO}_{4}$, and washed until the washings gave no test for the sulphate ion.

Eight cultures of four plants eaeh were set up in the following solutions:

$\begin{array}{lcl}\text { Solution } & \text { Treatment } & \text { Remarks } \\ \text { (a) Culture solution } & \text { None } & \text { Purified salts } \\ \text { (b) Culture solution } & \mathrm{H}_{2} \mathrm{SiO}_{3} & \text { Purified salts } \\ \text { (c) Culture solution } & \mathrm{H}_{2} \mathrm{SiO}_{3} & \text { Unpurified salts }\end{array}$

After being soaked and the hulls removed, the seed was germinated on paraffined mosquito netting. The seedlings were quite variable in size and, since it was assumed that plants growing without silieon would be the smallest, the best plants were chosen for this group, the next best for purified salts with silicon, and the smallest for the unpurified salts. It was hoped in this way to overeome apparent improvement with silicon which might be due to variability. The seedlings were transferred to the eulture solutions July \&.

The eulture solutions for this series were removed on the following dates: September 1, 12, and 23; October 4 and 23 ; November 22 and January 4. Solutions of the original strength were used until November 22, when they were replaced by solutions of one-half the original strength.

\section{OBSERTATIONS}

July 22. Plants in solutions with silicon appeared to be as large as those in solutions without.

September 11. Some leaves of the plants of the group without silicon were beginning to dry.

September 23. The number of dry leaves of plants of the group without silicon was increasing rather rapidly. There were but few dry leaves on plants of the other two groups. Leaves of the group without silicon appeared quite mottled. 
October 13. Guttation, which had been quite profuse for all plants from the beginning, had ceased in the group without silicon. It was still profuse on plants of the other two groups.

October 19. There was a marked decrease in the amount of guttation in the groups with silicon. Heads were beginning to develop in most cultures; there were fewest in the group without silicon.

November 13. Heads in the group without silicon were developing very slowly. Plants in the three groups appeared very different in size. The plants of the group without silicon were much the smaller and plants of the group in solutions of purified salts with silicon were smaller than those in solutions of unpurified salts with silicon. An exudate appearing like erystals, but really a viscous liquid, had formed on many leaves of the plants without silicon.

December 28. Heads of plants grown with silicon were much larger than those of the group without and appeared to be filling. A few leaves of the group in solutions of purified salts witl silicon had the exudate noted above for the group without silicon.

February 10. Plants harvested.

No seed matured in any of the cultures.

The roots of plants of the group without silicon were in poor condition and beginning to disintegrate. The roots of the two other groups were in good condition.

The roots were matted together, so were weighed per eulture (groups of four) and averaged. The average weights of roots and tops are given in table 3 .

\section{TABLE 3}

Average Dry Weight in Grams of Rice Plants Grown With axd Without SILICON

\begin{tabular}{|c|c|c|c|}
\hline Solution & No. of plants & Tops & Roots \\
\hline 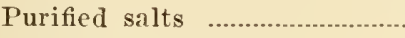 & $\ldots \quad 32$ & $3.29 \pm .34$ & 1.1 \\
\hline Purified salts + Si .................... & 32 & $5.33 \pm .37$ & 1.7 \\
\hline Jnpurified salts $+\mathrm{Si}$ & 32 & $6.58 \pm .45$ & 2.1 \\
\hline
\end{tabular}

The weights of the plants with silicon were greater than those of the plants without. In this case as in the aluminum series with peas, the unpurified salts gave the best growth, which indicates that the purified salts lacked not only the element to be studied, but one or more other elements not usually considered essential but which must play some rôle in plant nutrition. 


\section{Silicon Series with Millet}

Liberty millet was the variety employed for this experiment. It was afterward learned that it often gives a very poor yield of grain under field conditions.

The culture solution used was the same as that of the preceding series except that 2 p.p.m. of manganese in the form of $\mathrm{MnSO}_{4}$ was added.

Two groups of plants, one in solutions of purified salts, and the other in solutions of purified salts with silicon, were included in this series. Each group included 30 cultures of $t$ plants each.

Two-quart mason jars were employed as containers.

The seed was germinated on mosquito netting and the seedlings transferred to the culture sohtions March 29.

The plants grew rapidly and were begimning to head out April 10. Little difference could be noticed in the appearance of the two groups. The plants of the group with silicon appeared to be somewhat better.

Plants were harrested June 26.

All plants had heavy short roots with many fine short laterals. The roots of the plants with silicon had more fine laterals and were on the average about an inch longer than those without. There was little difference in the dry weights of the two groups. The yield of seed was very small, 23 seeds for plants grown without silicon, and 126 for plants grown with silicon. The seeds from the two groups of plants were quite different in appearance. Those grown with silicon were much more glossy and lighter in color.

The average weight per plant is given below:

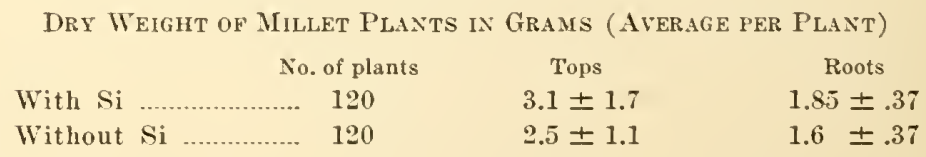

The difference in weight in this series is not large enough to be signifieant. The absolute difference in the number of seeds is large, but the total yield is too small to be of value. 


\section{Second Generation Series}

The seeds of the plants grown in the preceding experiment were used for a second generation series. All of the seeds of the group grown without silicon and an equal number grown with silicon were used. All of the seeds from the group grown with silicon, and most of the seeds of the group grown without silicon, germinated.

At the end of the first week after germination the seedlings of the group with silicon were larger than those of the group without. The plants were destroyed by mice before they could be transferred to the culture jars.

\section{Second Millet Series}

The culture solutions and the kind of millet seed used were the same as those of the preceding series.

Large containers of 16-liter capacity were employed. There were 2 cultures of 24 plants each, in each group. This series was transferred to the culture solutions September 28 and harvested January 7 .

\section{TABLE 4}

Description of Millet Plants Grown With and Without Silicon

Length of roots in $\mathrm{cm}$. $\begin{array}{ll}\text { With } \mathrm{Si} & \text { Without } \mathrm{Si} \\ \text { (48 plants) } & \text { (48 plants) }\end{array}$

Lengths of tops in $\mathrm{cm}$.

$24 \pm 4$

$52 \pm 7$

$31 \pm 4$

Dry weight of tops in $\mathrm{gm}$

$.44 \pm .09$

Total dry weight in gm.

$.45 \pm .11$

$.38 \pm .07$

Weight of seed per plant in gm.

$.13 \pm .04$

$.07 \pm .03$

The plants of this scries were very different in size and general appearance from those grown in the spring. They did not have as tall rigid stalks and the roots were much longer and finer. There were fewer roots from the crown and the laterals were very much longer. The plants were very variable in size.

There was a large difference in the yield of seeds with the same difference in appearance as was noted for the first series. The total weight of seeds for the group grown with silicon with 6.14 grams and that without silicon was 3.39 grams.

One of the two containers without silicon had larger plants with more seed than the other.

The average weights per plant and lengtlı of roots are given in table 4 above. 
Since the plants in one container without silicon were much larger than those in the other, it was thought well to get the averages for each container as these differences may have been due to contamination by dust. The values are given in table 5 .

TABLE 5

Description of Millet Plants Grown Without Silicon

\begin{tabular}{|c|c|c|}
\hline & Container I & Container II \\
\hline Length of roots in $\mathrm{cm}$. & $34 \pm t$ & $27 \pm 4$ \\
\hline Length of tops in $\mathrm{cm}$ & $47 \pm 6$ & $\pm 1 \pm 6$ \\
\hline Dry weight of tops in $\mathrm{gm}$. & $.33 \pm .06$ & $.25 \pm .06$ \\
\hline Total dry weight in gm. & $. \pm 3 \pm .08$ & $.33 \pm .06$ \\
\hline Weight of seed per plant in gm. & $.09 \pm .04$ & $.06 \pm .03$ \\
\hline
\end{tabular}

In the preceding series the roots of the plants grown with silicon were longer and heavier than those grown without. In this series the reverse was true. There was, however, sufficient increase in the dry weight of the tops for the plants grown with silicon to make the total dry weight greater than that of plants grown without silicon. The yield of seeds in this series was much larger and, since the plants with silicon produced nearly twice as much weight of seeds as the plants without silicon, this difference may be considered significant.

\section{Second Generation Millet Series With and Without Silicon}

Two hundred seeds of each group of the preceding series were used for a second generation experiment.

The netting and the germinating dish were covered with Valspar, and purified salts were used in making up the solution.

The seed of the plants grown without silicon germinated very poorly and in a few days were so covered with mold that they had to be discarded. There was 100 per cent germination of the seed of the plants grown with silicon, and, although they were germinated on the same piece of netting as the seed from plants grown without silicon, they were free from mold.

A second lot of seed, three hundred of each group. were treated with 1-5000 $\mathrm{IgCl}_{2}$ solution for thrce minutes, washed with sterile distilled water, and germinated under sterile conditions. The container, netting, and solution were sterilized and kept under a sterile bell jar. For the first four days no growth of fungi could be noticed, and the germination of the sceds from the plants grown with silicon was excellent, while that frou the silicon-free group was poor. After 
the fourth day a slight growth of mold could be seen on the seeds of the silicon-free group. This mold grew rapidly but did not attack the seed of the group grown in the presence of silicon.

The results of germination are as follows; all but two seeds of the group grown with silicon germinated:

\section{SILTCON-FREE GROUP}

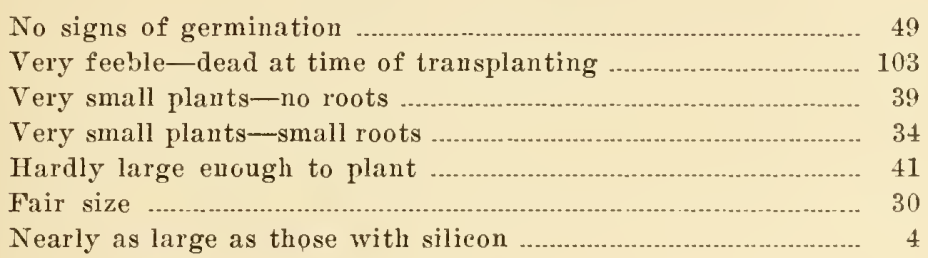

The seedlings are shown in figure 2.

Most of the larger plants of the silicon-free group were from seeds which came from the culture of the preceding series, which had produced the largest plants. One hundred and fifty seeds from each culture were used. The seeds from the two cultures were kept separate during germination. This is not shown by the picture because the line dividing them is at right angles to the line separating the two groups; that is, the seed from the plants grown with and without silicon.

Serenty-five plants of each group were transferred on April 28 to jars like those used in the preceding series. There were twenty-five plants to each jar.

\section{OBSERVATIONS}

May 8. Seven plants in the silicon-free series were dead.

May 15. The plants in two of the jars with silicon appeared less green and somewhat smaller than those of the other jar in that group. Examination showed their roots to be attacked by aphis. The covers of all jars were raised and "nicofume," an insecticide, was burned.

May 29. Aphids were on the roots of most of the plants. Nicofume was burned.

June 2. Most of the plants in two of the cultures of the group with silicon, and a few of the plants in two of the cultures without silicon, had heads.

June 15. Most of the plants in all cultures except one in the group with silicon had heads. The heads of the plants in this culture appeared to have been irjured when they were beginning to form. Small dry rudimentary heads were all that could be seen and they were present on all plants of this culture.

July 6. Aphis found on the roots and tops of most of the plants. Nicofume was burned.

July 21. The plants were harvested. 
One culture in the silicon-free group had only 2 seeds, another had 68 , and the third had none; the total weight was 0.37 grams. The weight of seed from the two cultures of the group with silicon which produced heads was 3.92 grams. The roots and tops were not weighed separately since some of the plants had slipped rather far down into the solution and had roots high up on the stalks. The average weight of plants grown with silicon was $2.1 \pm 0.5$ grams, that of plants without was $1.7 \pm 0.8$ grams.

The type of plant, with the exception of the plants in one of the jars without silicon (the jar to which the smallest seedlings had been transferred and where seven of the plants had (ied), was the same as that of the plants grown during the preceding spring. Those of the exceptional culture had roots like the plants grown in the fall and the tops were of an intermediate type. There was great variability in the size of the plants, especially with those grown without silicon.

The kind of differences for the second generation was the same as that for the first generation; that is, there was but little difference in dry weight between the groups with and without silicon, but a great difference in the yield of seed. The difference in the yield of seed was much greater in the second generation.

\section{Silicon Series with Penisitu a vilosum}

This plant was chosen because of the high silicon content of its leares. An analysis showed an ash content of 13 per cent, 75 per cent of which was $\mathrm{NiO}_{2}$.

The solution used was the same as that in the preceding series. One lnundred plants were included in each group, one witl and one without silicon, and two-quart mason jars were employed as contamers. There were four plants per jar.

The plants were transferred to the culture solutions February 21. They showed no signs of head production when they were harvested July 20. 


\section{OBSERVATIONS}

At the end of five weeks the plants grown with silicon were larger and greener than those grown without it. The leaves of those without silicon appeared mottled like those of the corresponding group of rice. By the time the plants had been transplanted eight weeks, they had so many tillers that part of the cork had to be cut away. Soon after this the plants in the silicon-free solutions began to grow rapidly and at the time of harvest appeared about as large as those grown with silicon. The leaves, however, were not so green. The leaves of the plants grown without silicon were much smoother than those grown with silicon. There was a tremendous variability in the size of the plants but the variability was much less by culture. The average weights are therefore reported as total dry weight per culture and are: with silicon $30.8 \pm 2.6$ grams; without silicon $29 \pm 1.8$ grams.

The average for the plants without silicon does not include one culture which was very much smaller than the others.

These results with Penisitum vilosum are ineonchusive, since there was for a while a marked difference in the apparent size of the plants of the two groups, which disappeared later on. This change was probably due to contamination, since it was impossible to shut out dust entirely-especially after part of the cork had been cut away.

In experiments with and without silicon, rice and Golden millet (that used in the aluminum series), showed very marked differences in dry weight; the increase when silicon was added being 60 per cent for the tops of rice and 50 per cent for the tops of millet. Liberty millet, on the other hand, showed no marked differences in dry weight, but the increase in yield of grain through the addition of silicon was large, especially in the second generation experiment, indicating that silicon may be essential to its growth, but that either the conditions under which it grew, in these experiments, were not sufficiently controlled, or that enough silicon is stored in the seed to carry the plants through at least two generations. 


\section{DISCUSSION}

Until recently the importance of small amounts of elements, other than iron, has received practically no attention. Bertrand had stressed the importance of manganese, but it remained for $\mathrm{MeHargue}{ }^{9}$ to prove it to be essential. The work of Mazé, ${ }^{8}$ indicating that there may be a considerable number of elements necessary in very small quantities, may explain why culture solutions made up with unpurified salts, when included in the series reported in this paper, gave the best yields. The results of Warington ${ }^{17}$ witl boron suggest that plants may differ in their requirements for ions. This was brought out accidentally by the writer in an attempt to grow ricia faba with and without ahuminum. The same salts were used as had been used for millet, but the beans grew only for a short time and showed the symptoms described by Warington, for boron-starved plants. Although they had ceased growing and were in very poor condition, the addition of 1/2 P.I.m. boron caused excellent new growth of both tops and roots.

The difference in the needs of different plants may, however, be one of amount rather than of kind of elements. The amount of certain elements needed for some plants may be so small that sufficient purification of salts used in relatively large amounts may be practically impossible. Stoklasa ${ }^{16}{ }^{16}$ work with hydrophytes, in which some of the plants failed to grow without the addition of aluminum, and the work of the writer with peas and millet, seem to bear out this idea. This seems also to be shown in the silieon experiments when we eompare the results of Kreuzhage and $W_{\text {oltht }}{ }^{6}$ with oats, and of the writer with millet, with the results obtained by the writer with rice. The significant results with oats and millet were ehiefly concerned with seed production, while with rice there was a very large difference in dry weight. 


\section{SUMMARY AND CONCLUSIONS}

Experiments were conducted to determine whether or not aluminum and silicon are essential to plant growth. Especially purified salts and redistilled water were used for culture solutions. All containers were coated to prevent solution of the glass.

The addition of aluminum to culture solutions in which peas were grown gave only a small increase in total dry weight but a somewhat greater increase in the amount of seed.

The addition of aluminum to culture solutions in which millet was grown gave a marked increase in growtl ; the increase in the amount of seed being very great. The results of this experiment strongly indicate that aluminum is essential to the normal development of millet.

Attempts to grow a second generation of peas and millet were unsuccessful, but seedlings from seeds grown with aluminum werc much better than those from seeds grown without it. The germination also, in the case of millet, was better with the seeds from plants grown with aluminum.

The improvement in the growtl of rice on the addition of silicon was great enough to indicate that silicon is essential to its growth.

The addition of silicon to culture solutions in which millet was grown gave marked increases in seed production and, in one series, a marked increase in both seeds and dry weight.

In a second generation series with millet, grown with and without silicon, the difference in dry weight was very slight but the yield of seed for plants grown with silicon was more than ten times as great as that for plants grown without it.

Sceds of millet grown without silicon were badly infected by fungi while those grown with silicon were not attacked.

An experiment with and without silicon in which Penisitum vilosum was used was inconclusive, since the marked differences which appeared after the first month disappeared later on. The change may have been due to contamination by dust. 


\section{LITERATURE CITED}

1 Abbott, J. B., Conner, S. C., And Smalley, H. R.

1913. Soil acidity, nitrification, and the toxicity of aluminum salts. Indiana Agr. Exp. Sta. Bull. 170.

2 DAVE, Sir HuMPhREY

1814. The elements of agricultural chemistry (New Fork, Estburn, Kirk \& Co.).

3 Hartwell, B. L., and Penber, F. R.

1918. The presence of aluminum as a reasou for difference in the effect of so-called acid soil on barley and rye. Soil Sci., vol. 6, p. 259.

4 JoDIx, V.

1883. Du rôle de la silice. C. R. Acad. Sei. Paris, vol. 97, p. 344.

5 KratzMan, E.

1914. Auf physiologischen Wirkung der Aluminum-salze auf die Pflanze. Anzeiger Akad. d. Wiss. Wein, math-naturw. Klasse, vol. 51, p. 195 .

6 Kreuzhage, C., und WolfF, E. ron

1884. Bedeutung der Kiesel-saüre für die Entwicklung der Haferpflanze nach Versuchen in Wasserkultur. Organ f. naturw. Forschungen, Landw. Vers.-stat. Dresden, vol. 30, pp. 169-197.

7 Liebig, J.

1946. Die Chemie in ihrer Anwendung die Agrikultur und Physiologie.

S MAZÉ, P.

1919. Recherche d'mne solution purament minerale capable d'assurer l'évolution du mais cultivée à l'abri des microbes. Ann. Inst. Pasteur, vol. 33, p. 139.

9 McHargue, J. S.

1922. The rôle of manganese in plants. Jour. Am. Chem. Soc., rol. 44 , p. 1592 .

10 Mirasol, J. J.

1920. Aluminum as a factor in soil acidity. Soil Sci., vol. 10, p. 153.

11 MIYакI, K.

1916. The toxic action of soluble aluminum salts upon the growth of the rice plant. Jour. Biol. Chem., vol. 25, p. 23.

12 Pierre, I.

1866. La silice et la verse des bles. C. R. Acad. Sci. Paris, vol. 63, p. 374. 13 Ruprecht, R. W.

1915. Toxic effect of iron and aluminum on clover seedlings. Mass. Agr. Exp. Sta. Bull. 161.

I+ SACHS, J.

1S62. Ergebnisse einer neurer Untersuchungen über die Pflanzen enthaltene Kieselsaur. Flora, n. s., vol. 20 (whole series, vol. 45), p. 33. 
15 SPrecher, A.

1911. The rôle of silicon in the nutrition of plants. Bull. Soc. Genéve, vol. 2 , series 3 , no. 4 , pp. 155-192.

16 STOKLASA, J.

1922. Über die Verbreitung des Aluminums in der Natur (Jena, Gustav Fischer).

17 WARINGTON, K.

1924. The effect of boric acid and boron on the broad bean and certain other plants. Ann. Bot., vol. 37, p. 629 . 
$$
\equiv \equiv \equiv \equiv \equiv \equiv \equiv \equiv \equiv \equiv \equiv \equiv \equiv
$$ 


\section{UNIVERSITY OF CATIFORNIA PUBLICATIONS-(Continued)}

BOTANY.-W. A. Setchell and R. C. Holman, Fditors. Volumes I-IV $\$ 3.50$ per volume; volume $V$ and following $\$ 5.00$ per volume. Volumes I (pp. 418), II (pp. 360 ), III (pp. 400), IV (pp. 397), V (pp. 589), VI (pp. 517), VII (pp. 506), IX (pp. 423), and X (pp. 437), completed. Volumes VIII, XI, XII, and XIII in progress.

Vol 8. 1. The Marine Algae of the Pacific Coast of North America. Part I. Myxophyceae, by Willam Albert Setchell and Nathaniel Iyon Gardner. Pp. 1-138, plates 1-8. November, 1919

2. (The same.) Part II. Chlorophyceae, bf William Albert Setchell and Nathaniel Iyon Gardner. Pp. 139-374, plates 9-33. July, 1920 ._..........

3. (The same.) Part II. Melanophyceae. Pp. 383-898, plates 34-107. June, 1925

Vol. 9. A Report upon the Boreal Flora of the Sierra Nevada of Callformia, by Frank Jason Smiley. 423 pages, 7 plates. October, 1921

V01.10. 1. The Genus Fucus on the Pacific Coast of North America, by Nathaniel Iyon Gardner. Pp. 1-180, pls. 1-60. April, 1922

2. Plantae Mexicanae Purpusianae, XI, by Townshend Stith Brandegeo. Pp. 181-188. November, 1922

3. A Revision of the Californian Species of Lotus, by Alice M. Ottley. Pp. 189-305, plates 61-82, 10 maps. August, 1923

4. Notes on a Collection of Now Zealand Hepaticae, by William Henry Pearson. Pp. 307-370, plates 83-103.

5. More New Zealand Hepaticae, by William Henry Pearson. Pp. 373-392, plates 104-109.

Nos. 4 and 5 in one cover. June, 1923

6. Parasitic Florideae II, by William Albert Setcholl. Pp. 393-396.

7. A Revision of tho West North American Specios of Callophyllis, by William Albert Sotchell. Pp. 397-401.

Nos. 6 and 7 in one cover. May, 1923

8. Plantae Mexicanae Purpusianae, by Townshend Stith Brandegee.' Pp. 403-421. September, 1924.

9. New Species of Plants from Indo-China, by Elmer D. Merrill, Pp. 423430. October, 1924

Vol. 11. 1. Interspecific Hybridization in. Nicotiana. 'On the Results of Backcrossing the $F_{1}$ Sylvestris-Tabacum Hybrids to Sylvestris, by Thomas Harper Goodspeed and Boy Ilwood Clausen. Pp. 1-30, 12 figures in text. August, 1922

2. Inheritance in Nicotiana Tabacum. VI. A Mendelian Analysis of Certain Flower Form, Flower and Filament Color, and Ieaf-base Characters, by M. A. Kelaney. Pp. 31-59, 6 figures in text. . August, 1925

V01. 12. 1. Iichenes a W. A. Setchell et H. E. Parks in Insula Tahiti a 1922 Collecti, scripsit Edv. A. Vainio. Pp. 1-16, January, 1924

2. Report upon a Collection of Ferns from Tahiti, by William A Mazon. Pp. 17-44, plates 1-6. May, 1924

3. Tahitian Mosses, Collected by W. A. Setchell and H. E. Parks, Determined by V. F. Brotherus. Pp. 45-48. September, 1924

Vol. 13. I Phycological Contributions. VII, by W. A. Setchell and N. I. Gardner. Pp. 1-13. October, 1924

2. Hemizonia congesta. A Genetic Ecologic and Taxonomic Study of the Hayfield Tarweeds, by Emest Brown Babcock and Margaret Mann Lesley. Pp. 15-100, 7 plates, 4 figures in text. December, 1924 .

3. Contributions Toward a Knowledge of the Life-histories of the Melanophyceae. A Preliminary Report, by Margaret Esther Myers. Pp. 109124 , plates 8-10.

4. Notes on Microdictyon, by William A. Setchell. Pp 101-107. Nos. 3 and 4 in one cover. September, 1925

5. Observations on the Origin of Secondary Dormant Buds in Deciduous Fruit Trees, by Bruno Hahne. Pp. 125-128, plate 11. January, 1926 


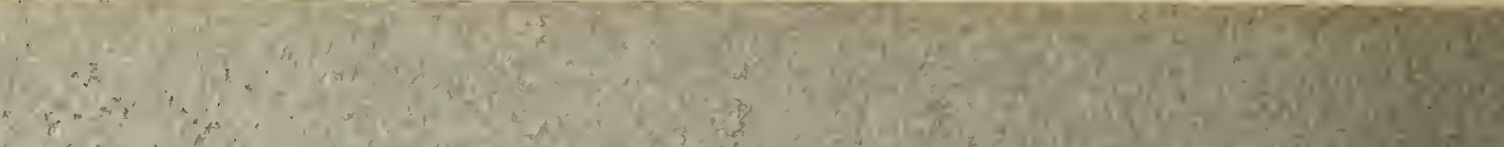

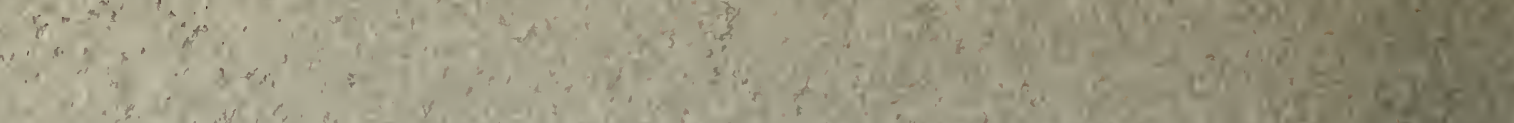

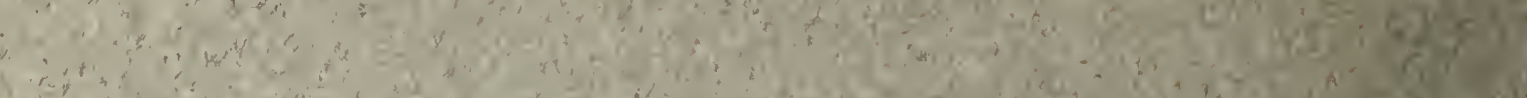
${ }^{4}$

(s) $=\frac{1}{2}=\frac{1}{2}$

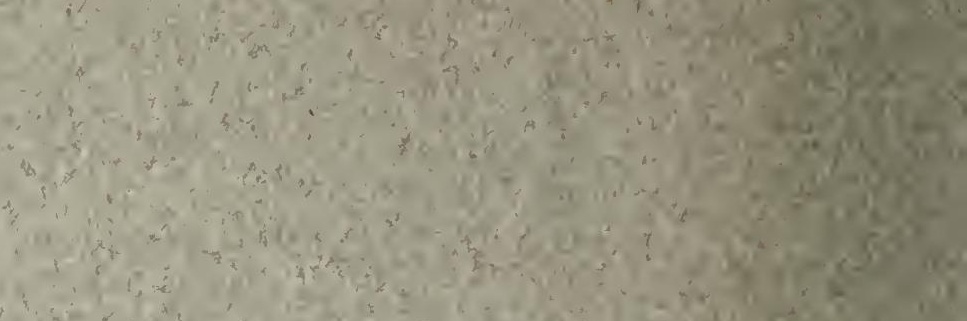
Q

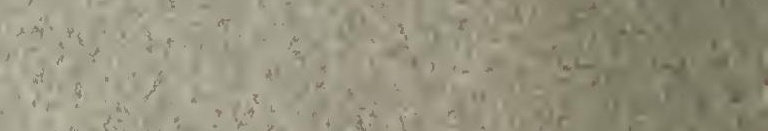
(1) a

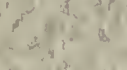

Wi:

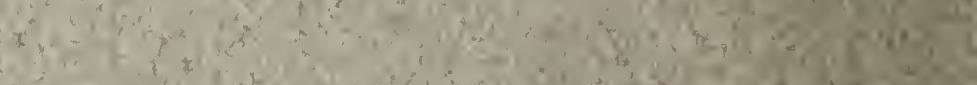

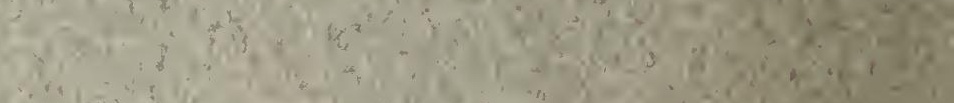

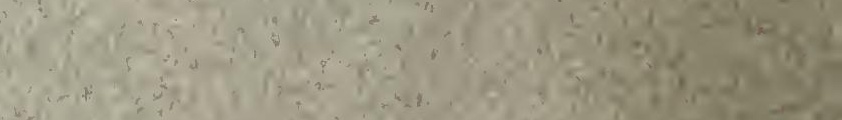
tistis $\rightarrow x^{2}$

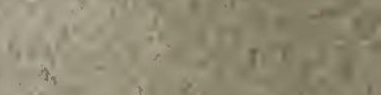

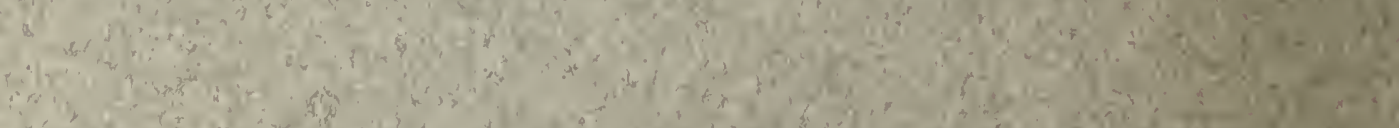

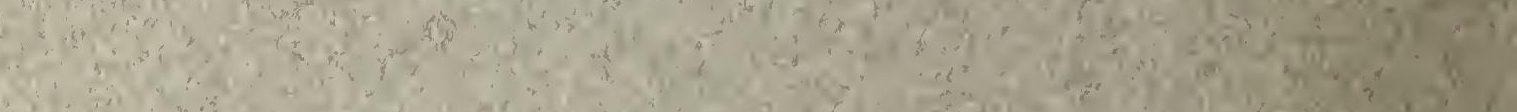

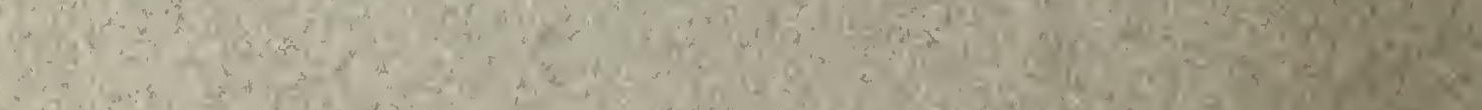
$x_{2} x_{1}=$

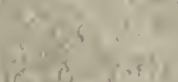
(6) a

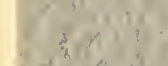

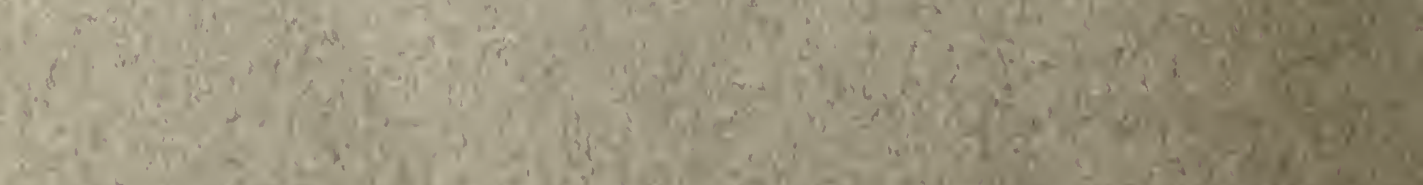

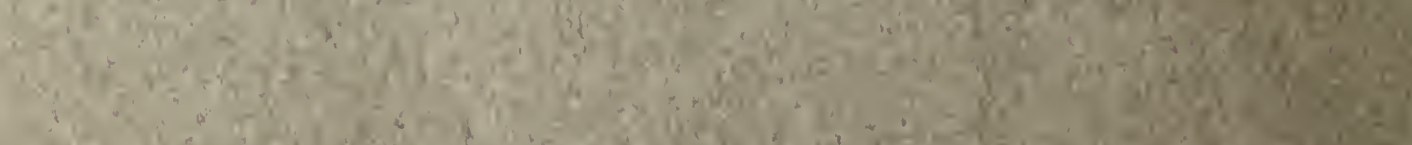
1
$x^{2}-1$ $2 x^{2}+x^{2}+x^{3}$ in

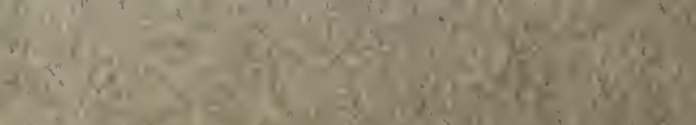

